\title{
Market Orientation and Firm Performance among Nigerian SMEs: The Moderating Role of Business Environment
}

\author{
Aliyu Mukhtar Shehu \\ Ph.D (Candidate), Othman Yeop Abdullah Graduate School of Business, University Utara Malaysia
}

\section{Rosli Mahmood}

School of Business Management, College of Business, University Utara Malaysia aliyumukhtarshehu@gmail.com

\section{Doi:10.5901/mjss.2014.v5n23p158}

\section{Abstract}

The purpose of this study is to examine the relationship between market orientation and firm performance, with the moderating variable of business environment. The study employed a cross sectional research design, using a structured questionnaire survey with a sample of 640 SMEs fully operational in Kano state, a total of 511 valid questionnaires were completed and returned representing 79.8 percent response rate. The finding from the study shows that the relationship between market orientation and firm performance was found to be insignificant; the relationship between the business environment and firm performance was also not significant also. The result of moderation indicated that the business environment was found to moderate on the relationship between market orientation and firm performance. The finding of this study will benefit owner/managers of SMEs, regulatory agencies, government at all levels and will also serve as a frame to future studies.

Keywords: Market orientation, Business environment, Firm performance, SMEs, Nigeria

\section{Introduction}

Market orientation refers to a business behavior which ensures that products and services are developed such that meet customer needs and expectations (Suliyanto \& Rahab, 2012; Polat \& Mutlu, 2012). In this association, a market- oriented firm shall involve the customer in designing the marketing mix in order to provide customer value. In support of this argument, Chen and Quester (2009) asserted that both the implementation of customer-centric thinking in marketing; and customer value creation are critical for achieving a positive business performance (Alhakimi and Baharun, 2009). Market orientation was first identified as the important determinant of a business' performance by Kohli and Jaworski (1990) and Narver and Slater (1990). Since the work of Kohli and Jaworski (1990) and Narver and Slater (1990), many studies have been done to try to establish the link between market orientation and firm performance. Most of these studies have found a strong positive correlation between market orientation and performance (Hooley et al., 2000; Shoman \& Rose, 2001; Grainer \& Padanyi, 2005; Olavarriete \& Friedman, 2008; Li \& Justin, 2008; Morgan et al, 2009; Dauda \& Akingbade, 2010); though there are a small number of studies that found no positive linear relationship between market orientation and firm's performance (Au \& Tse, 1995; Demirbag et al, 2006). Previous studies have suggested a direct relationship between market orientation and business performance, using the business environment as moderator (Suliyanto and Rahab, 2012). A review of the literature suggests that despite the many studies that have been undertaken to learn about market orientation, certain important variable such as the environment in which the business is conducted have not been given desired attention in the literature. This creates a gap in the market orientation-performance relationships.

Therefore, the paper is organized as follows: section two provides the literature review; section three methodology, sample and data collection, measurement of variables; section four is about the result including the goodness of measure as well as the hypothesis testing; section five provides the implication, limitations and the direction for future studies. 


\section{Literature Review}

\subsection{Firm performance}

According to Kanyabi and Devi (2012) performance is the measurement of financial ability of the firm such as the level of profit, investment level with both growth in sales and profit. Mandy (2009) viewed performance as the outcome of adapting effective management process. He posited that organizational performance can be measured using a number of criteria; which includes effectiveness, efficiency, growth and productivity. Firm effectiveness can be used to measure operation, finance as well as behavioral levels. First, financial measures may include profitability and growth. Second, measure of operation may include resource acquaintance, production level, employee attitude to work and so on. Third, behavioral effective is made up of adaptability, satisfaction and good interaction can be used to assess performance. He further lamented the performance determination process of a given firm which involves a choice of some variables that can allow organizations to be more intelligently acting. Olosula (2011) explained the performance concept as an ability to assess the level of success of a business organization be it small or big. SMEs can be evaluated in terms of employment level, firm size, strength in working capital as well as its profitability.

\subsection{Market orientation}

Polat and Mutlu (2012) viewed market orientation is seen as a firm's ability that is extremely valuable, rare, and that cannot easily imitated, with emphasis of placing the customer in the center of a firm's strategy and operations. The academic understanding of the MO concept is categorized into two as behavioral and cultural approaches respectively. Kohli and Jaworski (1990) are the proponents of behavioral approach, and they hypothesized that MO involves a set of activities directed towards making the customer happy. In contrary, Narver and Slater $(1990,2000)$ who are the advocates of cultural approach gave emphasis on the shared values of firm that consider customer interest as number one priority. According to Kohli and Jaworski (1990) as cited in Hooley (2000) market orientation is described as comprising intelligence generation, intelligence dissemination, and organization wide consciousness to it, whereas, Narver and Slater (1990) based on the cultural method, viewed market orientation as comprising customer orientation, competitor orientation and inter-functional coordination. Both these approaches are the same in the sense that customers remain the key component of market orientation thinking.

\subsection{Business environment}

According to Duncan (1972) business environment is considered to be the combination of physical and social factors that is reflected in the individual organization. Sul (2002) saw business environment as the flow of relevant knowledge which is significant of setting organizational objectives which have strong influence of managerial thinking. Therefore, business environment can be considered as the summation of those factors that are both internal, that is within the control of a single business firm and external factors that are beyond the control of a single business enterprise. Agboli and Likaegbu (2006) conceptualized business environment as events, situations and circumstances, settings and positions which surround entrepreneurial activities. Sul (2002) considered the following as the basic features of business environment: is complex in nature; is a constantly changing with changing situations; it is unique with different business units; it has both long term and short term impact; unlimited influence on external environmental factors; it is very unclear; it has interrelated mechanisms; it includes both internal and external background.

\subsection{Market orientation and firm performance}

Market orientation and firm performance, relationship have received a wider attention in the organizational and marketing literature over the last two decades. Kelson (2012) carried a quantitative study of market orientation and organizational performance of listed companies in Ghana. A total of twenty out of thirty seven listed companies participated with seventy two senior officials as respondents. The finding indicated that top management factor had a statistical significant relationship with market orientation, external factor had a statistical significant relationship with market orientation, and the overall performance of listed companies in Ghana was linked to market orientation. The finding of Jyoti and Sharma (2012) in their study on market orientation and business performance relationship. They reported a significant association between market orientation and business performance, and also a significant indirect relationship of employee and customer satisfaction in the relationship between market orientation and business performance. Oyedijo, Idris and Aliu 
(2012) equally investigated the impact of marketing practices on the performance of small business enterprises: empirical evidence from Nigeria. Their sample made up of five hundred and forty five businesses/ senior staff in Lagos-Nigeria, using survey questionnaire and analysis of variance (ANOVA) as a method of analysis. The finding of their study shows a linkage between marketing practices and overall firm performance. However, the study of Jaiyeoba (2014) established a significant positive relationship between market orientation behaviors in service firm's in Bostswana and both the economic and non - economic performance.

Similarly, Webster, Hammond and Rothwell (2014) investigated the market orientation effect on business performance of business schools that register with the association of advance collegiate schools of business in the US. One hundred and sixteen academic vice president and one hundred and thirty one deans were the respondents. The finding from their study indicated a significant and positive relationship between market orientation and performance. Additionally, the study of Kelson (2014) reported a significant relationship between market orientation and business performance of twenty four listed companies in Ghana. In the same vein, Wilson, Perepelkin, Zhang and Vachon (2014) investigated four hundred and fifty three Canadian medical biotechnology companies, and reported a significant and positive association between market orientation and performance. The above findings are in concord with each other, evidencing a significant positive relationship between market orientation and performance.

In contrast, Au, and Tse, (1995) in their study, which employed hotel as sample with marketing managers as respondents. The results indicated no significant association between market orientations and SME performance. Demirbag, Lenny Koh, Tatoglu and Zaim, (2006), conducted a study on TQM and market orientations impact on SMEs performance, using structural equation modeling for data analysis, with one hundred and forty one SMEs operating in the Turkish textile industry. They found no significant relationship between market orientation and organizational performance, the only relationship established was between market orientation and organizational performance with the mediation of TQM. However, the study of De luca, Verona and Vicara (2010) examined market orientation and research and development effectiveness in high - technology firms. The finding from the study reported a mixed result. Based on the prior arguments and other supporting ones, the following hypothesis was proposed to be empirically tested.

$H_{1}$ : There is a significant relationship between market orientation and firm performance among Nigerian SMEs

\subsection{Business environment and firm performance}

Lindsay, Tan and Campbell (2009) conducted a study on candidate performance on the business environment and concepts section of the CPA Examination. The business environment was used as an independent variable in the relationship between concept sections of the CPA examination. Additionally, Nandakurma, Ghobadian and Regan (2010) empirically examined four thousand five hundred and eleven US companies and the data were generated from leading commercial database. The study was carried out on business-level plan and performance, the moderating effects of environment and structure, using a survey questionnaire as an instrument and moderated regression method for data analysis. The findings reported a strong relationship between environment and competitive performance. However, Bruton, Filatotchev and Chahine (2010) examined UK and France the initial public offering (IPO) of two hundred and twenty four firms. They reported institutional environment as a good moderator on the relationship between governance, structure and IPO performance. Aswari (2010) assessed business environment for small and medium enterprises in Lebanon, which specifically focus on assessing the existing legal, regulatory and policy environment for small business growth in the country. The sampling frame made up of sixty four small enterprises using survey interview and descriptive statistics for the data analysis. The business environment was used here as an independent variable and the study recommended need for creating a conducive environment for smooth operation of small businesses in Lebanon.

Korunka, Kessler, Frank and Lueger (2010) argued about personal characteristics, resources, and environment as predictors of business survival using a survey questionnaire as an instrument and logistic regression for data analysis. The sampling frame was drawn from three hundred and fifty four small business owners observed over 8 years using longitudinal study. The environment was used as an independent variable, and the study reported that personal characteristics, resources, and environmental aspects at the start of business activities explain only a relatively small part of the variation in business survival. Similarly, Lee (2010) investigated one hundred and forty foreign firms in China, and reported that environment, market responsiveness, product innovation, and multinational corporations' network have strength on firm performance. In (2010) Rogerson and Rogerson investigated the factors that lead to the attainment of enabling business environment in Johannesburg, South Africa. The samples consist of one hundred foreign investor and ten business chambers, using survey interview and descriptive statistics for data analysis. The findings of the study indicated a similar finding obtained from the previous study of the World Bank. Aziz and Yasin (2010) reported that external environment (market technology turbulence and competitive intensity) was not a moderator of the relationship 
between market orientation and firm performance.

Abd Aziz (2010) examined the effect of the external environment on a business model and performance relationship with the external environment dimension of (turbulence, hostility and dynamism). The finding of the study indicated none of the external environment dimensions was significant as moderator on the relationship between business model and firm performance. Additionally, Sheng, Zhou and Li (2011) investigated on the effects of business and political ties on firm performance from a Chinese perspective. Samples of two hundred and forty one high technology firms were selected. The outcome from the study shows that business ties have a stronger positive effect on performance than political ties, and both effects depends on the institution and market environment respectively. In (2012) Ho, Wang and Vitell did a global analysis of corporate social performance with the effects of culture and geographic environment. A global CSP database of companies from forty nine countries was used. The findings established that Hofstede cultural dimensions are positively related to CSP. Europe companies were found to outperform other countries and regions in CSP.

The study of Yang, Wang, Zhu and Wu (2012), surveyed over five hundred senior executives of manufacturing and service firms in China. A cluster ordinary least square analysis was used. The result reveals that environment (technology) has a significant and positive influence on product innovation. Similarly, Babatunde and Adebisi (2012) examined strategic environmental scanning and organizational performance in a competitive business environment. They used a structured questionnaire for data collection with regression and correlation coefficient for data analysis. The finding of the study indicated a significant positive relationship between strategic environmental scanning and organizational performance. However, the finding of Jalali (2012) established that environmental determinants (hostility, turbulence and uncertainty) are important predictors of export performance. Based on the prior arguments and other supporting ones, the following hypothesis was proposed to be empirically tested:

$\mathrm{H}_{2}$ : There is a significant relationship between business environment and firm performance among Nigerian SMEs

$H_{3}$ : Business environment moderate the relationship between market orientation and firm performance among Nigerian SMEs

\section{Research Methodology}

\subsection{Sample and Data Collection}

The population consisted of 1829 small and medium enterprises fully operational in Kano state, northwestern part of Nigeria (SMEDAN, 2012). The study employed Kriejcie and Morgan (1970) method of sample selection. Based on this, a sample of 320 SMEs was selected. The sample size was doubled in order to take care of non - response issue as suggested by Hair et al, (2008). Therefore, 640 constituted the sample size of the present study. Out of 640 questionnaires administered, 511 were completed and returned representing 79.8 percent response rate.

\subsection{Measurement}

The measurement of firm performance and market orientations were adopted frm Suliyanto and Rahab (2012). A measure of business environment was adopted from the work of Abd Aziz (2011). All the items were assessed on a five point Likert scale ranging from 1 strongly disagree to 5 strongly agree.

\section{4. $\quad$ Result}

\subsection{Goodness of Measures}

In determining the accuracy of measures, reliability and validity methods were used. After calculating the PLS algorithm, the report indicated that cronbach's alpha coefficient ranges from 0.601 to 0.842 which is accepted, according to Sekaran $(2003,2010)$. A Conclusion can be made that the instrument adopted in this study are reliable.

All items loaded on their respective construct ranging from 0.751 to 0.902 , which, according to Hair et al (2010) is accepted as it is above the cut - off point of 0.5 . Similarly, the composite reliability values range from 0.726 to 0.875 which is also greater than the recommended value of 0.5 . In justifying the discriminant validity, the average variance extracted (AVE) is compared with the correlation squared of the variable in question which shows adequate convergent and discriminant validity. 


\subsection{Hypotheses Testing}

The present study examined the relationship between market orientation and performance of Nigerian SMEs, with the moderating variable of business environment. The interpretation of the hypotheses is summarized in table 2 . The result indicated that the relationship between market orientation and firm performance was not significant $(\beta=0.094, t=1.410$, $P<0.159)$, this is in line with the findings of Au and Tse (1995) in their studies on the effects of marketing orientations on company performance in the service sector established no significant relationship between market orientation and company performance. Demirbag et al (2006) also reported similar findings that market orientation was not a predictor of SME performance..hence hypotheses $\mathrm{H} 1$ is not supported. The relationship between the business environment and firm performance was found to be insignificant $(\beta=-0.009$, $t=0.111, P<0.911)$, this is in line with the finding of Sul (2002) who examined the relationship between the external environment, entrepreneurial strategy, mechanistic - organic structure and financial performance of restaurant franchisors from the perspective of franchises., thus $\mathrm{H} 2$ is rejected.

In testing for the moderating effect of business environment on the relationship between market orientation and firm performance $(\beta=0.265093, t=5.786857, P<0.0001)$. This finding shows that the business environment moderates the relationship market orientation and firm performance, the finding is in line with the previous finding of Kean et al (1998) in their study conducted on the effects of community characteristics, business environment and competitive strategies on rural retail performance. The finding indicated a significant and positive relationship between community measures of market size, business environment and small business performance. Nandakurma et al (2010) in their empirical study with four thousand, five hundred and eleven US companies as sample. The study was conducted on business level plan and performance, the moderating effects of environment and structure, using survey questionnaire and regression methods for data analysis. The result shows a strong relationship between environment and competitive performance. Additionally, Tsuja and Marlfio (2013) assessed the influence of the business environment on organizational innovation in service companies in Peru. They reported that uncertain environment promotes technical innovation; complex environment promotes both administrative and technical innovations; organizational characteristics partially mediate the relationship between administrative and technical innovations.

Similarly, the study of Iyer, Srivasto and Rawwas (2014) which align supply chain relational strategy with the market environment and implications for operational performance. A sample of one thousand four hundred and forty Chief executive officers was used as respondent, with smart PLS for data analysis and through mail questionnaire survey. The finding, reported that resource specificity, resource complimentarily, and collaboration have a significant positive association with market environment. Hence, $\mathrm{H} 3$ is supported.

\section{Implication, Limitations, and Direction for Future Research}

The finding from the present study will benefit SME owner/managers, small and medium enterprise development agency of Nigeria (SMEDAN), various arms of government and will also serve as a frame of future research. From the theoretical viewpoint, the study finding will add to the existing body of knowledge by adding moderator in the market orientation to performance relationship

The study has some methodological shortcomings. First, the study is cross sectional in nature, hence, the data were only collected at a point in time, the direct effect of the independent variable on the dependent variable is difficult to conclude. Secondly, the data from the study was collected from the owner/managers of randomly selected SMEs in Kano, another region and states were not included, hence, the impossibility of generalization.

Future studies should focus on specific industry such as manufacturing, service, agriculture, education and so on. Additionally, a qualitative method is suggested for an in-depth understanding of market orientation and firm performance relationship with the moderating role of business environment. Longitudinal study is also suggested for future research, with a data that will cover a wider geographical area. 


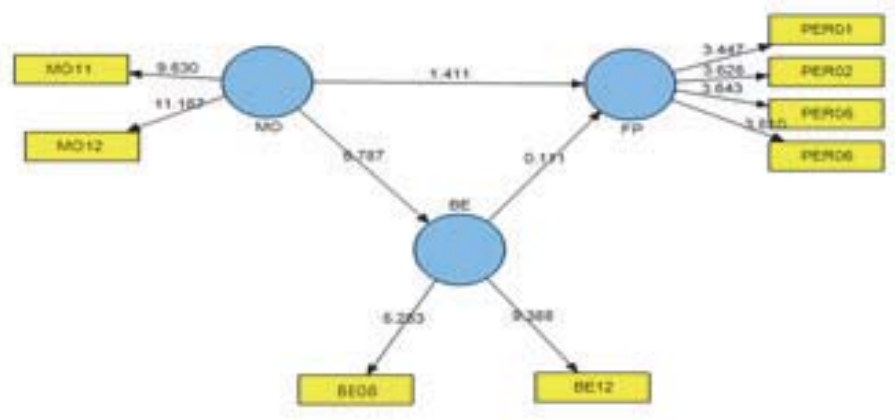

Figure 1. Research model

Table 1. Goodness of Measure

\begin{tabular}{cccccc}
\hline & Items & Loading & Cronbach's Alpha & Composite Reliability & AVE \\
\hline FP & Per01 & 0.75 & & & \\
& Per02 & 0.751 & & & \\
& Per05 & 0.902 & & 0.875 & 0.638 \\
& Per06 & 0.781 & 0.842 & & \\
MO & MO11 & 0.789 & & 0.774 & 0.631 \\
& MO12 & 0.8 & 0.625 & & \\
BE & BE08 & 0.774 & & 0.728 & 0.576 \\
& BE12 & 0.834 & 0.601 & & \\
\hline
\end{tabular}

Table 2. Path Coefficient and Hypotheses Testing

\begin{tabular}{|c|c|c|c|c|c|}
\hline Hypotheses & Path Coefficient & Standard Error & T Statistics & $P$ - Value & Decision \\
\hline BE -> FP & -0.009255 & 0.083291 & 0.11112 & 0.911 & Not Supported \\
\hline MO -> BE & 0.265093 & 0.045809 & 5.786857 & 0.0001 & Supported \\
\hline MO -> FP & 0.094985 & 0.067319 & 1.410966 & 0.159 & Not Supported \\
\hline
\end{tabular}

\section{References}

Abd Aziz, S., \& Mahmood, R. (2010). The relationship between business model and performance of manufacturing small and medium enterprises in Malaysia. African Journal of Business and Management, 5(22), 8919-8938. Retrieved fromhttp://www. academicjournal.org/AJBM.

Agboli, M., \& Ukaegbu, C.C. (2006). Business environment and entrepreneurial activity in Nigeria implications for industrial development. Journal of Modern African studies, 44(1), 1-30.

Alhakimi, W. and Baharun, R. (2009) A Synthesis Model of Market Orientation Constructs Toward Building Customer Value: A Theoretical Perspective, African Journal of Marketing Management, 1(2), 43- 49.

Asrawi, F. (2010). Assesing the business environment for small and medium size enterprise in Lebanon. International Journal of Business and Public Administration, 7(1),103-116.

Au, A.K.M., \& Tse, A.C.B. (1995). The effects of market orientation on company performance in the Service Sector: a comparative study in Hong Kong and New Zealand. Journal of International Consumer Marketing, 8(2), 77-87.

Babatunde, B. O., \& Adebisi, A.O. (2012). Strategic environmental scaning and organizational performance in a competitive business environment. Economic Insights - Trends and Challenges, 54(1), 24-34.

Bruton, G.D., Filatotchev, I., \& Chahine, S. (2010). Governance, ownership structure, and performance of IPO: The impact of different types of private equity investors and institutional environments. Strategic Management Journal, 31, 491-509.

Chen, S., \& Quester, P.G. (2009). A value based perspective of market orientation and customer service. Journal of Retailing Customer Services, 16(3), 197-206.

Dauda, Y.D.,\& Akingbade, W.A. (2010). Employee's Market orientation and Business performance in Nigerai: Analysis of small Business Entreprises in Lagos state. International Journal of Marketing Studies, 2 (2), 134-143.

De luca, L.M., Verona, G., \& Vicara, S. (2010). Market orientation and Research and Development effectiveness in the Biotechnology Industry. Journal of Production Innovation Magement, 27, 299-320.

Demirbag, M., Lenny Koh, S.C., Tatoglu, K., \& Zaim, S. (2006). TQM and Market orientations impact on SME's performance. Industrial Management and Data System, 106(8), 1206- 1228.

Duncan, R. G. (1972). Characteristics of organizational environments and perceived environmental uncertainty. Administrative Science Quarterly, 17, 313327.

Grainer, B., Padanyi, P. (2005). The relationship between market-oriented activities and market- oriented culture: implications for the development of market orientation in nonprofit service organizations. Journal of Business Research, 58, 854- 862.

Hair, J.F., Wolfinbarger, M.F., \& Ortinall, D.J. (2008). Essential of marketing Research. Boston: McGraw. Hill//rwin.

Hair, J. F., Andersen, R. E., \& Tatham, R. L.(2010). Multivariate data analysis (7thed.). Upper Saddle River, NJ: Pearson Prentice Hall. 
Hooley, G., Cox, T., Fahy, J., Shipley, D., Beracs, J., \& Fonfara, K. (2000). Market orientation in the transition economies of Central Europe: Tests of the Narver and Slater market orientation scales. Journal of Business Research, 50, 273-285.

Hou, J., \& Chien, Y. (2010). The effects of market knowledge management competence on business performance: A dynamic capabilities perspective. International Journal of Electronic Business Management, 8(2), 96-109.

Iyer, K.N., Srivastava, P., \& Rawwas, M.Y.A. (2014). Aligning supply chain relational strategy with the market environment: Implicaations for operational performance. Journal of Marketing Theory and Practice, 22(1), 53-72.

Jaiyeoba, O.O. (2014). Performance outcome of market orientation behaviors among Bostwana's small servive firms. Journal of Management Research, $6(1), 52-69$.

Jalali, S.H.(2012). Environmental Determinants, Entrepreneurial orientation and Export performance: Empirical Evidence from Iran. erbian Journal of Management, 7(2), 245- 255.

Jyoti, J., \& Sharma, J. (2012). Impact of market orientation on business performance: Role of employee satisfaction and customer satisfaction. Vision,16(4), 297-313.

Kanyabi, Y.,\& Devi, S. (2012). The impact of advisory services on Iranian SME performance: An empirical investigation of the role of professional accountants. African Journal Business Management, 43(2), 61-72.

Kean, A., Gaskill, L., Jasper, C., Shoop, B., Jolly, L., \& Leisyritz, C. (1998) Effects of community characteristics, business environment and competitive strategies on rural retail business performance. Journal of Small Business Management, 36(2), 45-57.

Kelson, A.K. (2012). A quantitative study of market orientation and organizational performance of listed companies: Evidence from Ghana. International Journal of Management and Marketing Research, 5(3), 101-114.

Kelson, S.A. (2014). The moderating role of organizational capabilities and internal marketing in market orientation and business success. Review of Business and Finance Studies, 5(1),1-17.

Kohli, A. K., \&Jaworski, B. J.(1990).Market orientation: The Construct, Research Propositions and management Implication. Journal of Marketing, 54, 1-18.

Koranka, C., Kessler, A., Frank, H., \& Lueger, M. (2010). Personal characteristics, resources, and environnient as predictors of business survival. Journal of Occupational and Organizational Psychology, 83, 1025-1051.

Krejcie, R.V., \& Morgan, D.W.(1970). Determining sample size for research activities. Educational and Psychological Measurement, 30, 601-610.

Li, Y., Yongbin, Z., Justin, T.\&\& Liu, Y. (2008). Moderating effects of Entrepreneurial orientation on market orientation- performance linkages: Evidence from Chinese small firms. Journal of Small Business Management, 46 (1), 113-133.

Lee, R.P. (2010). Extending the environment - strategy - performance frame work: The roles of multinational corporation network strength, market responsiveness, and product innovation. Journal of International Market, 18(4), 58-73.

Lindsay, D.H., Tan, B., \& Campbell, A. (2009). Candidate performance on the business environment and concepts section of the CPA Exam. American Journal of Business Education, 2(7), 35-41.

Mandy, M.K. (2009). The Relationship between Innovativeness and the Performance of small and Medium-size Enterprises (SMEs) of Malaysian manufacturing sector. International Journal of Management and Innovation, 1(2), 1-14.

Morgan, N.A., Douglas, W., Vorhies, W. (2009). Market orientation, market capabilities, and firm performance.Strategic Management Journal, 30, 909- 920.

Nandakumar, M. K., Ghobadian, A., \& Regan, N.O. (2010). Business-level strategy and performance: The moderating affect of environment and structure. Management Decision, 48(6), 907-939.

Narver, J.C. \& Slater, S.F. (1990). The effect of a market orientation on business profitability. Journal of Marketing, 5, 20-35.

Olavarrieta, S., \& Friedmann, R. (2008). Market orientation, knowledge-related resources and firm performance. Journal of Business Research, 61, 623630.

Olusola. O. A. (2011). Accounting Skill as a Performance Factor for Small Businesses in Nigeria. Journal of Emerging Trends in Economics and Management Sciences, 2(5), 372-378.

Oyedijo, A., Idris, A.A., \& Aliu, A.A. (2012). Impact of Marketing Practices on the performance of Small Business Enterprises: Empirical Evidence from Nigeria. European Journal of Economics, Finance and Administrative Sciences, 46, 130-146.

Polat, I., \& Mutlu, M.H. (2012). The impact of market orientation, entrepreneurial orientation, environmental uncertainty and internationalization speed of firm performance. European Researchers, 27(8/2), 1248-1254.

Rogerson, C. M., \& Rogerson, J. M. (2010). Improving the local business environment of Johannesburg. Development Southern Africa, 27(4), 577-593.

Sekaran, U., \& Bougie, R. (2010). Research methods for business: A skill building approach (5 $5^{\text {th }}$ ed.). Chichester: John Willey and Sons Ltd.

Sekaran, U. (2003). Research method for business (4th ed.). New York: John Wiley and sons, inc.

Sheng, S., Zhou, K.Z., Li, J.J. (2011). The effects of Business and Political Ties on Firm performance: Evidence from China. Journal of Marketing, 75, 1-15.

Shoham, A., \& Rose, G. M. (2001). Market orientation: A replication, cross- national comparison, and extension. Journal of Global Marketing, 14(4),5-25.

SMEDAN, (2012). Survey report on micro, small and medium enterprises in Nigeria. Nigerian Bureau of statistics and small and medium enterprises development agency of Nigeria.

Sul, H.K. (2002). An Exploratory Model of the Relationships among the External Environment, entrepreneurial Strategy, Mechanistic-organic Structure, and Financial Performance of restaurant Franchisors from the Perspective of Franchisees. Unpublished doctoral dissertation, Virginia polytechnic institute and state university.

Suliyanto \& Rahab(2012). The role of market orientation and learning orientation in improving innovativeness and performance of small and medium enterprises. Asian Social Sciences, 8 (1), 134-145.

Tsuja, P.Y., \& Marlfio, J.O. (2013). The influence of the environment on organizational innovation in Service companies in Peru. Review of Business Management, 15(49), 582-600.

Webster, R.L., Hammond, K.L., \& Rothwell, J.C. (2014). Market orientation effects on business performance: Views from inside and outside the business school. American Journal of Business Education, 7(1), 9-20.

Wilson, G.A., Perepkin, J., Zhang, D.D., \& Vachon, M. (2014). Market orientation, alliance orientation, and the business performance in the biotechnology in industry. Journal of Commercial Biotechnology, 20(2), 32-40.

Yang, Y., Wang, Q., Zhu, H., \& Wu, G. (2012). What are the Effective Strategic orientations for new Product Success under Different Environment? An Empirical study of Chinese Business. Journal of Production Innovation Management, 29(2), 166-179. 